Review article

\title{
Roles and Principles of Sterilisation Process in Palm Oil Mills
}

\author{
Yin Mee Thang ${ }^{1,2}$, Robiah Yunus ${ }^{1,3 *}$, Mohd Noriznan Mokhtar ${ }^{4}$, David Ross \\ Appleton $^{2}$, Ahmad Jaril Asis ${ }^{2}$, Pei San Kong ${ }^{2}$, Huey Fang Teh ${ }^{2}$ and Abdul Azis Ariffin ${ }^{1,5}$ \\ ${ }^{1}$ Institute of Advanced Technology, Universiti Putra Malaysia, 43400 UPM Serdang, Selangor, Malaysia \\ ${ }^{2}$ Sime Darby Plantation Berhad, Plantation Tower, No 2, Jalan PJU 1A/7, Ara Damansara, \\ 47301 Petaling Jaya, Selangor, Malaysia \\ ${ }^{3}$ Institute of Plantation Studies, Universiti Putra Malaysia, 43400 Serdang, Selangor, Malaysia \\ ${ }^{4}$ Faculty of Engineering, Universiti Putra Malaysia, 43400 Serdang, Selangor \\ ${ }^{5}$ Dolphin International Berhad, 17 \& 19, Jalan Puteri 5/20, Bandar Puteri, 47100 Puchong, Selangor, Malaysia
}

\begin{abstract}
ARTICLE INFO

\section{Article history:}

Received: 02 April 2021

Accepted: 19 August 2021

Published: 18 October 2021

DOI: https://doi.org/10.47836/pjst.29.4.26

E-mail addresses:

robiah@upm.edu.my (Robiah Yunus)

thangyinmee@gmail.com (Yin Mee Thang)

noriznan@upm.edu.my (Mohd Noriznan Mokhtar)

david.ross.appleton@simedarbyplantation.com (David Ross Appleton)

ahmadjarilasis@gmail.com (Ahmad Jaril Asis)

sylvia.kong.peisan@simedarbyplantation.com (Pei San Kong)

teh.huey.fang@simedarbyplantation.com (Huey Fang Teh)

docazis7@gmail.com (Abdul Azis Ariffin)

* Corresponding author
\end{abstract}

Sterilisation in palm oil mills is considered a pre-treatment process as it affects stripping efficiency and oil quality. Although sterilisation technology has been well-established in the palm oil milling industry, the roles and principles of sterilisation, particularly related to the chemical changes in fruits and stalks occurring during the process, have been rarely reported. The review begins with the background literature on the biochemical properties of the FFBs, such as the compositions of binding carbohydrates and the phenomena of natural fruit detachment. Followed by the harvesting practice to understand the type of FFBs supplied to the industry. In addition, a comparison of the well-established conventional and alternative sterilisation technologies and sterilisation functions is critically reviewed and assessed. Establishing the current sterilisation process initiatives to address the natural fruit's separation more efficiently in palm oil mills is important. Particularly visualise sterilisation as a breakup of specific binding carbohydrates that leads to strippability. It will provide a further understanding of the sterilisation mechanism, which would benefit the palm oil miller in optimising the processing of fresh fruit bunches. The information provided in this review is necessary to 
mitigate the percentage of unstripped bunches and reduce the oil losses and ultimately enhance the oil extraction rate.

Keywords: Abscission, fresh fruit bunch, palm oil, pre-treatment, sterilisation

\section{INTRODUCTION}

Natural fruit detachment in oil palm fruit at the abscission zone occurs in two stages (Henderson \& Osborne, 1994; Henderson \& Osborne, 1990; Osborne et al., 1992). Fruit separation at a fruit base usually occurs one to three days earlier than in any other position. All harvested FFBs delivered to palm oil mills must be processed regardless of any degree of ripeness to prevent further deterioration of their quality. Therefore, an optimum sterilisation process is important to strip all unripe and ripening fruits from the stalk.

In a typical palm oil milling process, different operations are involved to mechanically extract the oil from fleshy mesocarp fibres of fresh fruit bunches (FFBs). The oil extracted is crude palm oil (CPO). Generally, these involve sterilisation of the FFBs followed by stripping; the stripped fruits undergo digestion and mechanical pressing. Finally, the clarification step is to separate the oil phase from the mixture of oil-water, purification to remove FFBs debris, drying to remove the moisture until the acceptable level. Then the oil would be stored in a storage tank (Siew, 2011, Vincent et al., 2014).

A good sterilisation process has a large impact on the efficiency and effectiveness of the downstream milling process, particularly the strippability of the palm oil fruits and the final oil quality (Babatunde et al., 1988; Siew, 2011; Ariffin, 1991; Vincent et al., 2014). Sterilisation is the heart of the palm oil milling process. Most of the technology development in the palm oil milling industry so far has focused primarily on the alternative sterilisation techniques which aimed at improving the OER (Vincent et al., 2014; Sivasothy et al., 2005; Hadi et al., 2012; Sukaribin \& Khalid, 2009; Omar et al., 2017). Still, many incidences of unstripped bunches (USB), where some fruits are still attached to the stalk, occur due to inefficient sterilisation. It suggests that the reasons underlying the high USB issues are not well understood. The oil loss due to USB is reported that approximately $0.77 \%$ of the total oil loss occurs in a palm oil mill (Walat \& $\mathrm{Ng}, 2013$ ). It equates to RM 306.5 million based on an average CPO price of RM 2,000 in 2019 (MPOB, 2019).

So far, no attempt has been made to assess the fundamental issues that underline the oil palm fruit strippability or separation in these sterilisers. For instance, the effects of sterilisation conditions on the degradation of binding carbohydrates at the abscission zone of oil palm fruits are not well known. In addition, the conversion of lignocellulosic fibres into simpler sugars affects strippability as it facilitates the detachment of fruits from the bunch. Furthermore, no study on the suitability of current sterilisation parameters in processing the FFBs with different ripeness levels is available. Sterilisation could facilitate the rupture of the cell wall and the release of oil (Owolarafe \& Faborode, 2008). Therefore, 
a greater understanding of the chemical changes in fruit bunches, particularly the binding carbohydrates at the abscission zone, is necessary to align the sterilisation parameters with mimicking the separation of the natural fruits to gain insights on how to optimise the sterilisation process best to improve the strippability.

\section{ABSCISSION OF OIL PALM UPON RIPENING}

Oil palm is a sessile drupe; it produces a bunch containing 1000 to 3000 oil palm fruits. Oil deposition in the mesocarp starts at about 15 weeks after pollination (WAP) and continues until fruit maturity at around 20-22 WAP (Sambanthamurthi et al., 2000; Teh et al., 2013). The bunch at this stage is ready for harvesting - lipid content accumulated up to the optimum level. At the same time, sugars such as glucose and fructose and the moisture were decreased to a deficient level. As a result, the carotene content was fluctuated during the development stage and recorded as about $600 \mathrm{ppm}$ to $700 \mathrm{ppm}$ at $20 \mathrm{WAP}$ onwards. The tocopherols and tocotrienols were increased from 20 WAP onwards (Sambanthamurthi et al., 2000).

Natural fruit detachment at the abscission zone occurs in oil palms in two stages (Henderson \& Osborne, 1994; Henderson \& Osborne, 1990; Osborne et al., 1992). The abscission zone of oil palm is shown in Figure 1. The first stage of abscission is induced at the junction of the fruit and its pedicel, which is regulated by ethylene. It is observed that in ripening fruit, some of the cells are loosely associated at pedicel while others still adhered along the fruit-based pedicel junction. At this point, the fruit is firmly held within the surrounding cup of the rudimentary androecial ring, the tepals, bracteoles, and spiny floral bract; full cell communication remains.

Nevertheless, in the second stage, the cells in this whole perimeter change the cell wall adhesion when the fruit is ripe and then abscised. It generally occurs at the inner face of the rudimentary androecial ring, and this second stage of separation is not directly

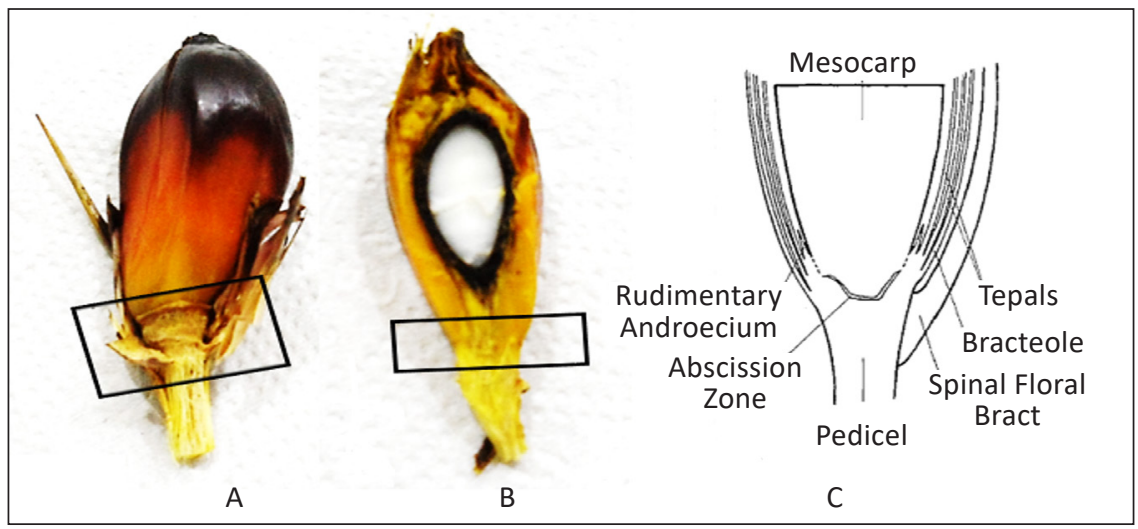

Figure 1. Abscission layer (rectangle area) of an oil palm fruit. A, with tepal attached; B, halve view, C, abscission zone 
responsive to ethylene. Hence, it suggested that regulating saccharide fragments or other degradation products of middle lamella or cell wall hydrolase such as endo- $\beta$ - 1,4 -glucan hydrolase initiate the second stage cell separation after the first stage (Payasi et al., 2009; Roongsattham et al., 2012). Henderson et al. (2001) found that high pectic polysaccharides are present in the oil palm abscission zone compared to those adjacent mesocarp and pedicel tissue to the abscission zone. They also reported that the cell walls of the abscission zone contain high levels of unmethylated pectin and polygalacturonase enzyme expression during fruit ripening and fruit detachment.

Fruit separation at a fruit base usually occurs one to three days earlier than in any other position. Therefore, even when cell separation at the fruit base is complete, the fruit is not shed (Henderson \& Osborne, 1990; Henderson \& Osborne, 1994; Osborne et al., 1992). However, unripe fruit will not separate at any position. As a result, this non-synchronous detachment of oil palm fruit as each fruit ripens raises a problem internal harvesting schedule due to the lack of reliable ripeness indicators of these many-fruited bunches in oil palm estates (Sambanthamurthi et al., 2000; Tan et al., 2010; Razali et al., 2012; Zulkifli $\&$ Ropandi, 2001). In oil palm plantations, the detachment and fall of the ripe fruit from its oil palm fruit bunches are taken to indicate the readiness for harvesting.

All harvested FFBs delivered to palm oil mills must be processed regardless of any degree of ripeness to prevent further deterioration of their quality. Therefore, an understanding of bunch ripening is important if harvesting is done correctly (Corley \& Tinker, 2003; Ariffin, 2010). Furthermore, an optimum sterilisation process is important to strip all unripe and ripening fruitlets from the stalk. Therefore, characterisation of FFBs prior to the sterilisation process is in need. However, no study has sought a profiling pattern between the binding carbohydrates characteristics and the manual ripeness determinations of FFBs delivered to the palm oil mill. These FFBs may differ from those of controlled bunches from the trial plot because of unidentified bunch age and containing a certain degree of damage due to the handling during transportation. Research mainly focuses on palm biomass lignocellulosic composition after the oil extraction.

\section{STERILISATION PROCESS IN PALM OIL MILLS}

\section{Conventional Steriliser Technology}

The most common sterilisation process in palm oil mills is in pressure vessels of varying designs: cylindrical vessels lying in horizontal, vertical, tilting or oblique positions, and spherical vessels. All sterilisers share similar operating parameters of $40 \mathrm{psi}$ to $45 \mathrm{psi}$ and residence time of 60 minutes to 90 minutes (Hassan et al., 1994; Halim et al., 2009). In addition, different steam cycles such as single, double, and triple peaks are put in place to improve the heat transfer during the sterilisation by stripping off the air trapped inside the steriliser to enhance further sterilisation efficiency. Sterilisation also can be operated 
as a continuous process that works at a lower steam pressure, such as atmospheric steam pressure (Vincent et al., 2014; Sivasothy et al., 2005).

The horizontal steriliser is the most commonly used in palm oil mills. It has a single hinged door at one end in which the FFBs are cooked by direct contact with steam (Halim et al., 2009). The FFBs are spread out uniformly in the cages with a low stacking height. When the pressurised steam is injected, it can reach out to different directions and corners of the contents within the cages. Low stacking height also minimises fruit bunch compression, which consequently minimises the bruising of the fruits. However, poor air removal is observed, especially during the earlier venting stage of the sterilisation. Thus, to remove the air from the pockets of space within the stacked fruit bunches, high steam consumption is required when using horizontal sterilisers, which operate using multiple-peak cycles. $\mathrm{KM}$ (2013) reported that about $360 \mathrm{~kg}$ to $400 \mathrm{~kg}$ of process steam per tonne of FFB is required for a horizontal steriliser operating at a steam temperature of $143^{\circ} \mathrm{C}$ and 4 bar absolute steam pressure in a triple-peak cycle. The disadvantage of a horizontal steriliser is the extensive maintenance and labour cost (cages management).

Aside from horizontal sterilisers, FFBs can also place directly into tall vertical sterilisers without steel cages. The vessel's height is restricted by the height of the building and the limited space of the loading ramp. Due to the stacking height in vertical sterilisers, the rate of bruised FFBs is high. It is reported that about $305 \mathrm{~kg}$ to $355 \mathrm{~kg}$ of steam per tonne of FFB was required for vertical sterilisers operating at a steam temperature of $143^{\circ} \mathrm{C}$ in triple-peak cycles for about 60 minutes (KM, 2013).

Meanwhile, a smaller capacity is allowable in spherical sterilisation, specifically a $25 \mathrm{~m}^{3}$ spherical steriliser enclosed with a top opening for filling the FFBs and a bottom condensate drain. It can be rotated 360 degrees to facilitate both FFBs feeding and discharge through a single door. Spherical steriliser consumes 220 to $250 \mathrm{~kg}$ of steam per ton of FFB over a steaming time of 60 minutes in a two-peak cycle (CIMG, 2015, Kumaradevan et al., 2015).

According to Sivasothy et al. (2005), Tan et al. (1999), and Hadi et al. (2012), the batch sterilisation required a longer steaming period and vast quantities of steam to heat the steriliser cage as well as to ensure complete heating up to the inner layer of the bulky FFB. Therefore, it is slow and inefficient as compared to the continuous sterilisation process. Continuous sterilisation is an alternative to batch process sterilisation, where it is operated at atmospheric pressure (Sivasothy et al., 2005; Sivasothy et al., 2006; Loh, 1994). This type of sterilisation is carried out in a heating chamber subjected to steam at atmospheric pressure continuously. FFBs are transported to a double-roll crusher for crushing before entering the heating chamber to expose to steam at atmospheric pressure through a scraper conveyor. The crushing of FFBs facilitates steam penetration into the inner layers of the fruit bunch (Sivasothy et al., 2006; Sivasothy \& Rohaya, 2000, Fatin et al., 2014).

The crushed bunches are immediately pre-heated to $60^{\circ} \mathrm{C}$ to facilitate deaeration, minimise the amount of air entering the chamber, and ensure that the temperature in the 
continuous sterilisation chamber is close to saturated steam. The bunches are heated for about 60 minutes inside the chamber using live steam. The bottom of the feed conveyor is filled with water to seal against steam loss (Sivasothy et al., 2005; Sivasothy et al., 2006). A continuous stream of steam gives consistent steam at the required temperature in a continuous steriliser. Consequently, steam consumption is the highest among the different sterilisers due to prolonged exposure time. It is reported that about $300 \mathrm{~kg}$ to 360 $\mathrm{kg}$ of steam per tonne of FFB was required for a continuous steriliser operating at a steam temperature of $98^{\circ} \mathrm{C}$ for about 60 minutes.

In addition, a continuous steriliser requires the second stage of post-heating to maintain a high temperature of stripped fruits to complete its heat treatment (Sivasothy et al., 2006; KM, 2013). Furthermore, Fatin et al. (2014) reported that better heat penetration in the chopped FFBs enhances strippability after sterilisation; however, the chopped FFBs must be sterilised within 30 minutes to preserve a good quality of the palm oil. Sivasothy et al. (2006) indicated that fewer unstripped bunches (USB) were noticed in conventional sterilisation $(2.13 \%)$ as opposed to continuous sterilisation $(24.1 \%)$ at the early stage of development in continuous sterilisation. A summary of sterilisation technology in the oil palm industry is tabulated in Table 1 .

The continuous sterilisation process is fundamentally different from the batch process in how the material flows. In general, a palm oil mill operating for about 16 hours to 20 hours a day depends on the availability of FFBs and other factors, which diminishes the advantages of continuous sterilisation. The disruption of FFBs supply will result in the loss of the throughput and efficiency of the operation (Aziz, 2003). In addition, issues such as high steam consumption, the extra cost associated with additional facilities such as the bunch crusher and moving scraper conveyor, pre-heating section, the double process of uncooked bunches need to be addressed to make the continuous sterilisation more economically viable.

Table 1

Summary of current sterilisation technology

\begin{tabular}{|c|c|c|c|c|c|}
\hline Characterisation & Horizontal & Vertical & Spherical & Tilting & Continuous \\
\hline Cooking time & $\begin{array}{c}\text { Standard } \\
100-120 \text { mins }\end{array}$ & $\begin{array}{c}\text { Standard } \\
>120 \text { mins }\end{array}$ & $\begin{array}{c}\text { Short } \\
60 \text { mins }\end{array}$ & $\begin{array}{c}\text { Short } \\
60-80 \text { mins }\end{array}$ & $\begin{array}{c}\text { Short } \\
70-85 \text { mins }\end{array}$ \\
\hline Pressure & $\begin{array}{l}\text { High } \\
40 \text { psi }\end{array}$ & $\begin{array}{l}\text { High } \\
30-40 \text { psi }\end{array}$ & $\begin{array}{l}\text { High } \\
45 \text { psi }\end{array}$ & $\begin{array}{l}\text { High } \\
\text { 40-45 psi }\end{array}$ & Atmospheric \\
\hline $\begin{array}{l}\text { Numbers of pressure } \\
\text { peak cycle }\end{array}$ & Triple & Triple & Double & Triple & Single \\
\hline Presence of cage & Yes & No & No & No & No \\
\hline Steam consumption & $\begin{array}{c}\text { High } \\
\text { 360-400 kg/ } \\
\text { MT FFB }\end{array}$ & $\begin{array}{c}\text { Moderate } \\
305-355 \mathrm{~kg} / \\
\text { MT FFB }\end{array}$ & $\begin{array}{c}\text { Low } \\
220-250 \mathrm{~kg} / \\
\text { MT FFB }\end{array}$ & $\begin{array}{c}\text { Low } \\
200 \\
\mathrm{~kg} / \mathrm{MT} \text { FFB }\end{array}$ & $\begin{array}{c}\text { Moderate } \\
300-360 \mathrm{~kg} / \\
\text { MT FFB }\end{array}$ \\
\hline
\end{tabular}




\section{Alternatives to Steriliser Technology}

Intensive studies are carried out to replace the conventional sterilisation process in palm oil mills. Sterilisation technology such as dry heating or coupled with solvent extraction was studied by Chow and Ma (2007) and Hadi et al. (2012). Sivasothy et al. (2006) and Hadi et al. (2012) found that the content of free fatty acid (FFA) of CPO obtained from continuous sterilisation and dry heating are similar to that obtained using conventional batch sterilisation. However, extreme dry heating can potentially cause the burning of oil palm fruits and difficulty in depericarping operation. Therefore, optimum heating time is crucial to loosen the nut from its mesocarp and keep the kernel in good condition for further processing at the same time.

Microwave energy is used in the low-temperature microwave sterilisation approach (Sarah \& Taib, 2013; Sukaribin \& Khalid, 2009; Umudee et al., 2013). This approach is operated at a low temperature of $100^{\circ} \mathrm{C}$ as it is aimed to preserve the oil quality compared to the conventional sterilisation that operated at $140^{\circ} \mathrm{C}$ (Vincent et al., 2014; Chow \& Ma, 2007). Sukaribin and Khalid (2009) found that microwave radiation can detach the fruits from the bunch without damage to the other regions of the bunch. They found that the abscission zone contains the highest dielectric properties than other regions, leading to higher microwave power absorbed at this region. The moisture content at the abscission zone was found almost 5 to 7 times higher than the mesocarp, helped in conducting the ionic constituents, subsequently contributed to the enhancement in the dielectric properties. These properties provide a good heating effect to detach the fruits from the stalk. Strippability of $80 \%$ was observed after 12 and 14 minutes heating with $1.5 \mathrm{~kW}$ and $1 \mathrm{~kW}$ microwave power, respectively. Khalid et al. (1996) suggested having separate microwave heating for FFBs and losing fruits due to their moisture content variation. Lengthy microwave heating exposure, similar to dry heating, would cause the burning of the oil palm fruits. However, current microwave and dry heating only accommodate spikelets or small amounts of fruitlets at one time. Therefore, industrial-scale microwaves and ovens should be studied to confirm their feasibility for sterilisation FFBs.

Waterless sterilisation, which uses supercritical carbon dioxide, autoclave, and enzymes to recover oil from fresh and sterilised palm fruits, was also reported in literature pieces. For example, Omar et al. (2017) reported the complete inactivation of lipase-producing microbes in ripe loose fruits using supercritical carbon dioxide at $10 \mathrm{MPa}$ pressure, at $80^{\circ} \mathrm{C}$ for 60 minutes. The treated fruits were found in shinning and glossy appearance with the presence of $\beta$-carotene.

Domínguez et al. (1994) reported that mixtures of enzymes were used to degrade the cell wall materials to enhance the oil extractability from oilseeds. Enzymes commonly used are hemicellulolytic or cellulolytic enzymes such as amylase, glucanase, protease, pectinase. It is possible via hydrolysis of the cell wall materials to facilitate the release of oil. Eshtiaghi 
et al. (2015) investigated the oil extraction using commercially available enzymes such as Cellic CTec2 (a blend of cellulases, beta-glucosidases, and hemicellulose), Cellic HTec2 (endoxylanase with soluble hemicellulose specificity), and Pectinex Ultra SP-L (an enzyme with rich pectolytic activities). Oil recovery of $88 \%$ was achieved by treating the sterilised fruit with the mixtures of Cellic CTec2, Cellic HTec2, and Pectinex Ultra SP-L at the ratio of 0.46: 0.34: 0.2. The enzyme loading was set as $30 \mathrm{mg} / 10 \mathrm{~g}$ substrate, substrate loading of $50 \% \mathrm{w} / \mathrm{v}, \mathrm{pH} 4.8$, and 2 hours of incubation at $50^{\circ} \mathrm{C}$. Silvamany and Jahim (2015) proposed that the enzyme type and concentration and the enzymatic treatment time were important for oil extraction from palm mesocarp to reduce the remaining pressed pulp. The cellulose concentration ranging from $0.05 \%$ to $0.15 \%$ reduced about $13 \%$ to $18 \%$ of the remaining pressed pulp, respectively, after 4 hours of enzyme treatment at $50^{\circ} \mathrm{C}$. Oil recovery of $88 \%$ to $95 \%$ was reported with different concentrations of cellulase, respectively.

It is revealed that successful applications of new technology can increase yield without compromising the quality of the oil extracted. The effluent generated in the milling process could also be reduced effectively by applying these technologies. However, these approaches require expensive technological advancement and are mostly still in their early stage; some approaches are labour intensive. Sultana (2007) stated that the best heating method for sterilisation is to use wet steam. Sterilisation under high humidity conditions is effective - hydrolysis and denaturation occur at lower heat and shorter exposure times than in the absence of water.

\section{FUNCTIONS OF STERILISATION}

\section{Deactivation of Lipase}

The level of FFA is one of the major indications of oil quality. Therefore, various experiments were conducted to study the level of FFA during fruit development. As a result, active endogenous lipase in the oil palm mesocarp was reported (Mohankumar et al., 1990; Henderson \& Osborne, 1991; Sambanthamurthi et al.,1991). Furthermore, lipase activity in the oil palm mesocarp is found synchronised with triacylglycerol biosynthesis. The lipase activity was determined at 16 weeks after anthesis (WAP), reached a maximum level at 21 WAP, and declined after 21 WAP.

Therefore, sterilisation's initial objective was to inhibit lipase activity in the pulp (Mongana report, 1955). It can be easily achieved by heating the palm fruits to about $60^{\circ} \mathrm{C}$. Sambanthamurthi et al. (1991) and Chong and Sambanthamurthi (1993) suggested that lipolytic enzyme is possibly only present in ripe fruits. Therefore, its activity could be related to the degree of ripeness of the fruit. They investigated the loose, ripe, and unripe fruits, which were bruised and left at ambient temperature for 4 hours, followed by sterilisation and then oil extraction. It was revealed that the FFA in the unripe bruised fruits was $0.16 \%$, which is relatively low compared to $2.06 \%$ of FFA of ripe bruised fruits. 
Notably, 9.45\% of FFA was observed in loose bruised fruits. Henderson and Osborne (1990) also reported hydrolase inside the palm fruit that can hydrolyse valuable triglycerides of the mesocarp to undesirable FFA. The autocatalytic and enzymatic hydrolysis occurred spontaneously at a temperature of less than $50^{\circ} \mathrm{C}$, in the presence of moisture, dirt, and infection by microbes such as Pseudomonas fluorescens and Geotrichum candidum that are capable of splitting fat (Menon, 2013).

Ngando-Ebongue et al. (2006) found that the calcium-dependent lipase is abundantly present in the mesocarp and represents a few per cent of total proteins. Lipase is compartmentalised within the cell and only comes into contact with the oil if cell membranes are damaged (Mongana Report, 1955; Corley \& Tinker, 2003). Therefore, FFB must be processed immediately after harvesting to prevent an unacceptable rise of FFA in oils. In addition, the enzyme is brought into contact with oil when the fruit is bruised, which can be caused by falling on the ground during harvesting, loading, transportation, and discharge from the lorry into steriliser cages (Ngando-Ebongue et al., 2006; Hadi et al., 2009).

\section{Loosening of Fruits and Softening of Mesocarp Tissue}

The second objective of sterilisation is to soften the mesocarp tissues and loosen the fruits to facilitate the subsequent mechanical stripping step. The deformation properties of both the abscission and mesocarp layers are affected markedly by the thermal softening process. After sterilisation, the fruit's fracturability at both abscission and mesocarp layers was reduced by $18 \%$ and $51 \%$, respectively (Abbas et al., 2006). Furthermore, the hardness values of the sterilised fruitlets for both abscission and mesocarp layers were reduced by approximately $84 \%$ compared to that of the fresh fruitlets. In addition, the adhesiveness values for both sterilised abscission and mesocarp layers were reduced by $91 \%$ and $60 \%$, respectively, as compared to that of fresh fruit.

\section{Facilitating Separation of Mesocarp Layer from Kernel Shell}

On top of the sterilisation as mentioned earlier, sterilisation, helps isolate the mesocarp layer from the kernel shell to minimise kernel breakage at the oil pressing stage (Sivasothy et al., 1992). The heat penetrates the nut that might affect the quality of nut-cracking through triple peak sterilisation. If the fruit is hot and the kernel shell may be sufficiently elastic to deform temporarily during pressing. If the fruits are well-cooked using triple peak sterilisation, wet nuts with $15 \%$ moisture in the nut and $20 \%$ moisture in the kernel can be cracked with $98 \%$ cracking efficiency without any broken kernels. Therefore, to minimise nut breakage during pressing, the digested fruit should be at about $100^{\circ} \mathrm{C}$ at the press station (Menon, 2013). 
Yin Mee Thang, Robiah Yunus, Mohd Noriznan Mokhtar, David Ross Appleton,

Ahmad Jaril Asis, Pei San Kong, Huey Fang Teh and Abdul Azis Ariffin

\section{A NEW PERSPECTIVE OF STERILISATION AS A CHEMICAL REACTION SYSTEM}

Different types of sterilisation technology have distinct pros and cons. For instance, issues with an uneven steam distribution occur in horizontal sterilisation, and many bruised FFBs are found in vertical sterilisation. Therefore, chopped FFBs are required prior to sterilisation in continuous sterilisers. Furthermore, research and development are still needed in microwave-assisted sterilisation and enzymatic sterilisation. Multiple pressure cycles with optimum air sweeping and bleed off enhance strippability, but high steam consumption is required in batch sterilisation. In addition, extreme sterilisation conditions lead to water loss and result in poor strippability. Applications of new technology can increase yield and without compromising the quality of the oil extracted. However, the incidences of USB are yet to address, as the efficiency of sterilisation was evaluated by measuring the percentage of USB.

Therefore, the heat transfer phenomena during sterilisation need to be investigated. Poor milling efficiency could be due to the typical palm oil milling process. The stalk is processed together with the FFB, which may cause difficulties of heat penetration, especially to those fruits located at the centre of a large and compact bunch. In addition, insufficient steam supply reduces the steam temperature to the sterilisers. As a result, the heat transmitted to the FFBs might be insufficient to achieve good sterilisation within the fixed period; this will eventually affect the FFBs strippability as reflected in the percentage of USB. Arif et al. (2016) observed that less heat was transferred inside the FFB stalks $\left(0.00054^{\circ} \mathrm{C} / \mathrm{s}\right.$ to $\left.0.00977^{\circ} \mathrm{C} / \mathrm{s}\right)$ as compared to sections near or beside the stalk $\left(0.01988^{\circ} \mathrm{C} / \mathrm{s}\right.$ to $0.02228^{\circ} \mathrm{C} / \mathrm{s}$ ). Moreover, fluctuation of heat transfer was observed due to inconsistent steam penetration towards the inside of the FFBs stalk. Babatunde et al. (1988) performed a comparative study that revealed $52 \%$ of the sterilised fruits were stripped after sterilisation at $100^{\circ} \mathrm{C}$ for 120 minutes, compared to about $95 \%$ of fruits stripped after 50 minutes of sterilisation at $130^{\circ} \mathrm{C}$.

Low strippability was observed if air occluded in the bunch did not remove efficiently; this is due to low thermal conductivity caused by the compact nature of the fruits. The thermal conductivity of air is about 10 times lower than that of oil and 30 times lower than water. Ariffin (1991) and Sivasothy et al. $(1992,1994)$ reported that the introduction of the pollination by the weevil, Elaeidobius Kamerunicus, in 1981 had increased the difficulty of heat penetration to larger and more closely packed multi-layer fruitlets during sterilisation. Therefore, it is important to remove as much air as possible during sterilisation. Air not only acts as a barrier to heat transfer, but oil oxidation increases considerably at high temperatures. Therefore, it can affect the quality, such as the poor bleachability of the product oil. In a horizontal steriliser, different air-steam mixture compositions are observed at various points of the sterilising process after a short time of sweeping, ranging from 0.1 
$\mathrm{L}$ to $200 \mathrm{~L}$ of air $/ \mathrm{kg}$ of steam from the top to the bottom of the steriliser. Therefore, it is also important to monitor the evacuation of the air content during the sterilisation process slowly and progressively. It is suggested to sweep the air with steam for 10 minutes at a rate of $100 \mathrm{~kg} / \mathrm{hr}$ to expel almost $90 \%$ of air from the steriliser (Menon, 2012; Menon, 2013). Concurrently, the condensate formed will also need to be removed from the vessel to prevent it from interfering with the heat transfer within the steriliser (Sivasothy et al., 1992).

The sterilisation temperature is vital as a sufficiently high temperature is required (above $100^{\circ} \mathrm{C}$ ) for an optimum period (more than 50 minutes) to allow the heat to penetrate the pericarp, especially into the attachment point of the fruits to the stalk. The research found that an hour is required for the bunch core to reach a temperature of $130^{\circ} \mathrm{C}$ to $135^{\circ} \mathrm{C}$ (Babatunde et al., 1988; Sivasothy et al., 2005; Leuenberger, 2001; Vincent et al., 2014). However, the optimum temperature and duration required for certain weights and sizes of FFBs are not well known in the actual situation. As there is no indication when the $100 \%$ strippability has reached during the sterilisation. Hence, the chances of getting a USB still occur.

Therefore, let us look at sterilisation from a different angle. Particularly visualise sterilisation as a breakup of specific binding carbohydrates that leads to strippability. Sterilisation is viewed as a chemical reaction where the binding carbohydrates are degraded, as illustrated in Figure 2 (modified from Hubbe et al., 2018; D’Alessandro E \& Pliego Jr, 2018). Carbohydrates are commonly divided into monosaccharides, oligosaccharides, and polysaccharides. Monosaccharides are polyhydroxy-aldehydes or-ketones, generally with an unbranched carbon chain. Glucose, fructose, and galactose are their common representatives. In contrast, oligosaccharides are carbohydrates obtained from $<10$ carbohydrate units, formally dehydrated to form monosaccharides. While polysaccharides, consisting of numerous monosaccharides that can up to $>10$ units. Hence, the polysaccharides are often considerably less soluble in water than mono- and oligosaccharides. The wellknown representatives are starch, cellulose, and pectin (Belitz et al., 2009). Elevated temperatures with sufficient water enhanced

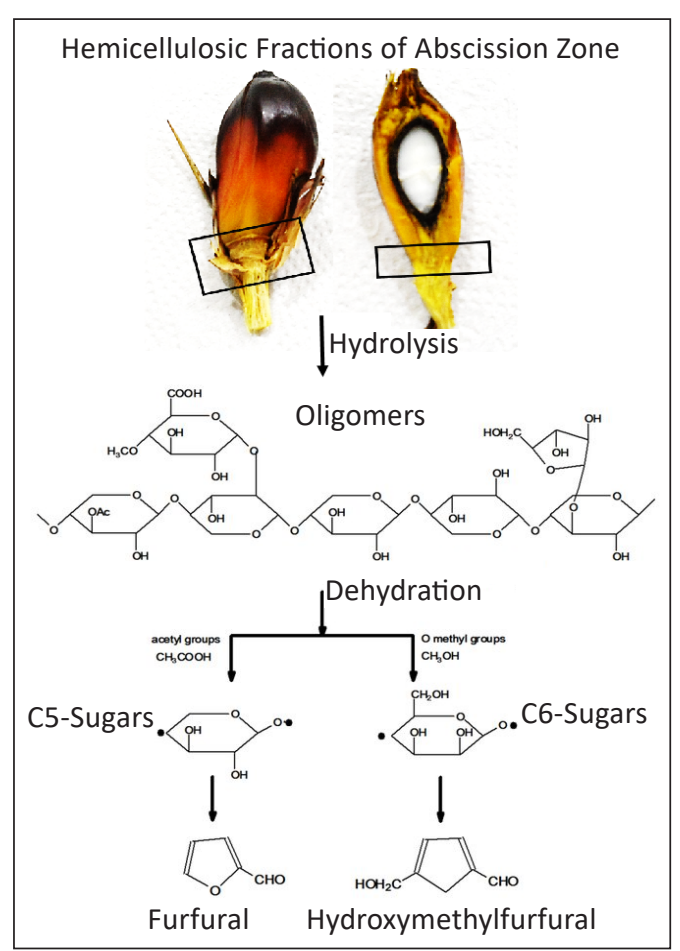

Figure 2. Schematic presentation of a breakdown of binding carbohydrates at the abscission zone of FFB 
the hydrolysis of cell wall materials into oligo-intermediates before the formation of monomers such as glucose and xylose (Mittal et al., 2009; Jacobsen \& Wyman, 2000; Lloyd \& Wyman, 2003; Hubbe et al., 2018; D’Alessandro \& Pliego Jr, 2018). Some can be further dehydrated and produce hydroxymethylfurfural and furfural (Lloyd \& Wyman, 2003).

It is assumed that better heat penetration efficiency during the sterilisation process will result in a higher rate of degradation of lignocellulosic fibres to sugars, thus a higher percentage of strippability. The energy supplied into the steriliser is used to break the binding carbohydrates of the abscission zone, and therefore the fruit can be mechanically detached from the stalk. The heat penetration induces a breakage of the cells connecting the fruit to the stalk during the sterilisation stage. An effective sterilisation process can ensure optimum hydrolytic degradation of the binding carbohydrates within fruits to stalk and consequently maximising the detachment of fruits. However, limited research has been done on the heat treatment to enhance the depolymerisation of cell walls during sterilisation. The binding carbohydrates of oil palm fruits were investigated by Silvamany and Jahim (2015). The result showed that the sterilised oil palm fruits contain extractive, moisture, hemicellulose, $\alpha$-cellulose, and soluble lignin, as tabulated in Table 2.

On the other hand, Thang et al. (2017) reported that the water-soluble sugar content from oil palm fruits subjected to autoclave treatment ranged from $3.2 \%$ to $3.6 \%$. Sucrose and glucose were found between $0.34 \%$ and $0.54 \%$ for all samples. The water-soluble sugar content was found slightly higher than non-structural carbohydrates due to the hydrolysis of cell wall materials during high-temperature autoclaves. Babatunde et al. (1988) reported that the cell wall materials of the fruit tissue could be depolymerised at temperatures above $48^{\circ} \mathrm{C}$ and dehydrated at temperatures above $115^{\circ} \mathrm{C}$. Besides, the degradation of binding carbohydrates at the abscission zone of FFBs during sterilisation could be established by analysing the sugars compositions in the steriliser condensates. The sugars may be leached into the steriliser condensate during the sterilisation or degraded. Ariffin et al.

Table 2

Composition analysis of palm mesocarp

\begin{tabular}{lc}
\hline Characterisation & $\%$ \\
\hline Total lipid content & 56.68 \\
Soluble sugars & 2.89 \\
Total structural carbohydrates & 13.76 \\
Glucan & 8.27 \\
Xylan & 4.52 \\
Arabinan & 0.97 \\
Soluble lignin & 3.58 \\
Insoluble lignin & 0.038 \\
Water extractive & 17.16 \\
Ethanol extractive & 17.98 \\
\hline
\end{tabular}

Table 3

Sugar content in steriliser condensate and sludge

\begin{tabular}{lcc}
\hline Sugar & $\begin{array}{c}\text { Condensate } \\
(\mathrm{ppm})\end{array}$ & $\begin{array}{c}\text { Sludge } \\
(\mathrm{ppm})\end{array}$ \\
\hline Glucose & 120.54 & 170.75 \\
Fructose & 123.59 & 175.96 \\
L-Sorbose & 139.53 & 197.44 \\
D-Ribose & 166.48 & 251.47 \\
L-Arabinose & 149.85 & 233.06 \\
D-Galactose & 160.16 & 248.02 \\
Maltose & 265.28 & 411.35 \\
Xylose & 133.48 & 207.35 \\
Mannose & 137.94 & 256.37 \\
\hline
\end{tabular}


(1993) reported that various soluble sugars were analysed in steriliser condensate and sludge obtained from palm oil mill (Table 3). It has been evidenced that sterilisation via hydrolysis of the binding carbohydrates facilitates the release of oil.

Therefore, the mechanism of the heating process and its relationship with cell walls degradation to enhance strippability should be further investigated. FFBs delivered to the mills comprise fruits with different degrees of ripeness. Hence, an optimum sterilisation process is important to ensure all fruits at different ripeness levels are being stripped from the stalk. This action allows specific chemical changes such as rupture of vessels, swelling or elongation of the connecting tissue cells, and modification of pectic compounds (Mongana Report, 1955; Hassan et al., 1994). In addition, the composition of the sugars of the sterilised fruit or the condensate could be used as an indicator to optimise the sterilisation parameter to achieve $100 \%$ strippability with zero USB.

\section{CONCLUSION}

This review has summarised the current steriliser technologies used in palm oil mills, including horizontal, vertical, spherical and continuous sterilisers. The roles and principles of the sterilisation process in palm oil mills have also been elucidated. To date, it can be concluded that horizontal sterilisers (batch process) and continuous sterilisers (continuous process) are the most promising technologies owing to their large scale production and ability to produce crude palm oil with low FFA. Potential replacements for conventional sterilisers such as solvent extraction and microwave-assisted sterilisation to improve the oil extraction rate and reduce oil losses have also been studied. However, the effects of sterilisation conditions on FFBs with different ripeness categories based on the chemical changes in the binding carbohydrates at the abscission zone and relate the effects to the fruits strippability should be evaluated. An effective and optimised sterilisation process with sufficient heat penetration at the point of abscission zone ensure hydrolytic degradation of these binding carbohydrates and maximise of the detachment of fruits from the bunch to be developed.

\section{ACKNOWLEDGEMENTS}

The authors are grateful to Sime Darby Plantation Bhd and Universiti Putra Malaysia LRGS 5526100 for the guidance, encouragement, and funding for the success and permission to publish this paper.

\section{REFERENCES}

Abbas, S. A., Ali, S., Halim, S. I. M., Fakhrul-Razi, A., Yunus, R., \& Choong, T. S. Y. (2006). Effect of thermal softening on the textural properties of palm oil fruitlets. Journal of Food Engineering, 76(4), 626-631. https://doi.org/10.1016/j.jfoodeng.2005.06.013 
Arif, H., Wahad, M. A., \& Sobri, T. M. (2016a). Model validation for temperature profile inside FFB during sterilization for palm oil mill process. Journal of Engineering and Applied Sciences, 11(15), 9029-9038.

Ariffin, A. A. (1991). Chemical changes during sterilization process affecting strippability and oil quality. Seminar on Developments in Palm Oil Milling Technology and Environmental Management. Genting Highlands (pp.2-12). PORIM.

Ariffin, A. A. (2010, May 11-13). Ripeness standards and palm fruit maturity affecting oil extraction rate (OER). [Paper Presented] 2011 International Conference and Exhibition of Palm Oil, Jakarta, Indonesia.

Ariffin, A. A., Rosnah, M. S., Muhamadiah, B., Zailan, W. O. W., \& Hasamudin, W. H. W. (1993, August 1819). Biochemical study of sterilizer condensate and sludge from palm oil mill. [Paper Presented]. 1993 National Seminar on Advances in Environmental Control Technology, Kuala Lumpur, Malaysia.

Aziz, M. K. A. (2003). The study of heat penetration in palm oil fruitlets by developing a new technique for measuring oil content in fruitlet during sterilization process. Universiti Teknologi Malaysia Institutional Repository.

Babatunde, O. O., Ige, M. T., \& Makanjuola, G. A. (1988). Effect of sterilization on fruit recovery in oil palm fruit processing. Journal of Agricultural Engineering Research, 41(2), 75-79. https://doi.org/10.1016/00218634(88)90190-4

Belitz, H., Grosch, W., \& Schieberle, P. (2009). Carbohydrates. In H. Belitz, W. Grosch, \& P. Schieberle (Eds.), Food Chemistry (pp. 248-339). Springer. http://dx.doi.org/10.1007/978-3-540-69934-7

Chong, C. L., \& Sambanthamurthi, R. (1993). Effects of mesocarp bruising on the rate of free fatty acid release in oil palm fruits. International Biodeterioration \& Biodegradation, 31, 65-70. https://doi. org/10.1016/0964-8305(93)90015-T

Chow, M. C., \& Ma, A. N. (2007). Processing of fresh palm fruits using microwaves. Journal of Microwave Power Electromagnetic Energy, 40(3), 165-173. https://doi.org/10.1080/08327823.2005.11688538.

CIMG. (2015). 3C spherical FFB sterilizer 2.0 - A cost-efficient tool in palm oil extraction in the 21 st century. CIMG Resources Sdn Bhd. Retrieved August 19, 2013, from http://spherical-sterilizer-palm-oil-mill. blogspot.com/2015/03/3c-spherical-ffb-sterilizer.html

Corley, R. H. V., \& Tinker, P. B. (2003). The products of the oil palm and their extraction. In The Oil Palm (pp. 445-466). Blackwell Publishing.

D’Alessandro E., \& Pliego Jr, J. (2018). Fast screening of solvents for simultaneous extraction of furfural, 5-hydroxymethylfurfural and levulinic acid from aqueous solution using SMD solvation free energies. Journal of the Brazilian Chemical Society, 29(2), 430-434. http://dx.doi.org/10.21577/0103-5053.20170140

Domínguez, H., Núnez, M. J., \& Lema, J. M. (1994). Enzymatic pretreatment to enhance oil extraction from fruits and oil seeds: A review. Food Chemistry, 49(3), 271-286. https://doi.org/10.1016/03088146(94)90172-4

Eshtiaghi, M. N., Paoplook, K., Yoswathana, N., \& Kuldiloke, J. (2015). Enhanced oil extraction from palm fruit mesocarp using technical enzymes. International Journal of Advances in Science Engineering and Technology, 3(1), 42-45. 
Fatin, S. A., Rosnah, S., \& Robiah, Y. (2014). The effect of storage time of chopped oil palm fruit bunches on the palm oil quality. Agriculture and Agricultural Science Procedia, 2, 165-172.

Hadi, N. A., Ng, M. H., Choo, Y. M., \& Ma, A. N. (2012). Dry heating of palm fruits: Effect on selected parameters. American Journal of Engineering and Applied Sciences, 5(2), 128-131.

Hadi, S., Ahmad, D., \& Akande, F. B. (2009). Determination of the bruise indexes of oil palm fruits. Journal of Food Engineering, 95, 322-326. https://doi.org/10.3844/ajeassp.2012.128.131

Halim, S., Mustafa, K., \& Noor, A. (2009). Research work on steam accumulator in palm oil mill. European Journal of Scientific Research, 37(4), 542-552.

Hassan, A. H., Basiron, Y., Sukaimi, J., Loke, K. H., Salleh, H., \& Hasan, N. B. (1994). Sterilization. In Palm Oil Factory Process Handbook Part 1 - General Description of the Palm Oil Milling process (pp. 17-29). Palm Oil Research Institute of Malaysia.

Henderson, J., \& Osborne, D. (1990). Cell separation and anatomy of abscission in the oil palm, Elaeis guineensis Jacq. Journal of Experimental Botany, 41(223), 203-210.

Henderson, J., \& Osborne, D. J. (1991). Lipase activity in ripening and mature fruit of the oil palm. Stability in vivo and in vitro. Phytochemistry, 30(4), 1073-1078. https://doi.org/10.1016/S0031-9422(00)95175-6

Henderson, J., \& Osborne, D. J. (1994). Inter-tissue signalling during the two-phase abscission in oil palm fruit. Journal of Experimental Botany, 42(276), 943-951.

Henderson, J., Davies, H. A., Heyes, S. J., \& Osborne, D. J. (2001). The study of a monocotyledon abscission zone using microscopic, chemical, enzymatic and solid state 13C CP/MAS NMR analyses. Phytochemistry, 56(2), 131-139. https://doi.org/10.1016/S0031-9422(00)00447-7

Hubbe, M., Pizzi, A., Zhang, H., \& Halis, R. (2018). Critical links governing performance of self-binding and natural binders for hot-pressed reconstituted lignocellulosic board without added formaldehyde: A review. Bioresources, 13(1), 2049-2115.

Jacobsen, S. E., \& Wyman, C. E. (2000). Cellulose and hemicellulose hydrolysis models for application to current and novel pretreatment processes. Applied Biochemistry and Biotechnology, 84, 81-96. https:// doi.org/10.1385/ABAB:84-86:1-9:81

Khalid, K. B., Zahariah, Z., \& Yusof, W. D. W. (1996). Variation of dielectric properties of oil palm mesocarp with moisture content and fruit maturity at microwave frequencies. Elaeis, 8(2), 83-91.

KM. (2013). Selection of sterilizer technology for energy efficient operation of palm oil mills. ENERGYWISE. Retrieved September 23, 2013, from http://rank.com.my/energywise/?p=310\#sthash.XLTPqAJj.dpbs.

Kumaradevan, D., Chuah, K. H., Moey, L. K., Mohan, V., \& Wan, W. T. (2015). Optimising the operational parameters of a spherical steriliser for the treatment of oil palm fresh fruit bunch. IOP Conference Series: Materials Science and Engineering, 88, 1-6.

Leuenberger, H. (2001). Physical basic of steam sterilization. Retrieved August 18, 2015, from http://www. pharma.unibas.ch/technology/index.html.

Lloyd, T., \& Wyman, C. E. (2003). Application of a depolymerization model for predicting thermochemical hydrolysis of hemicellulose. Applied Biochemistry and Biotechnology, 105, 53-67. https://doi.org/10.1385/ ABAB:105:1-3:53 
Loh, T. W. (1994, July 7-8). Innovative methods in oil processing/ oil palm industry. In Proceedings of the 1994 PORIM National Palm Oil Milling and Refining Technology Conference (pp. 75-80). Kuala Lumpur, Malaysia.

Menon, N. R. (2012). Innovation potentials in palm oil mill design. Palm Oil Engineering Bulletin, 104, 21-34.

Menon, N. R. (2013). Process review: Part 1. Palm Oil Engineering Bulletin, 108, 21-34.

Mittal, A., Chatterjee, S. G., Scott, G. M., \& Amidon, T. E. (2009) Modeling xylan solubilization during autohydrolysis of sugar maple and aspen wood chips: Reaction kinetics and mass transfer. Chemical Engineering Science, 64(13), 3031-41. https://doi.org/10.1016/j.ces.2009.03.011

Mohankumar, C., Arumughan, C., \& Kaleysaraj, R. (1990). Histological localization of oil palm fruit Lipase. Journal of the American Oil Chemists 'Society, 67(10), 665-669. https://doi.org/10.1007/BF02540419

Mongana Report (1955). Research on production \& storage of palm oil. Institute for the advancement of Scientific Research in Industry \& Agriculture.

MPOB. (2019). Oil extraction rate. Malaysia Palm Oil Board.

Ngando-Ebongue, G. F., Dhouib, R., Carrière, F., Zollo, P. H. A., \& Arondel, V. (2006). Assaying lipase activity from oil palm frui (Elaeis guineensis Jacq.) mesocarp. Plant Physiology and Biochemistry, 44(10), 611617. https://doi.org/10.1016/j.plaphy.2006.09.006

Omar, A. K. M., Norsalwani, T. L. T., Khalil, H. P. S. A., Nagao, H., Zuknik, M. H., Hossain, M. S., \& Norulaini, N. A. N. (2017). Waterless sterilization of oil palm fruitlets using supercritical carbon dioxide. The Journal of Supercritical Fluid, 126, 65-71. https://doi.org/10.1016/j.supflu.2017.02.019

Osborne, D. J., Henderson, J., \& Corley, R. H. V. (1992). Controlling fruit-shedding in the oil palm. Endeavour, 16(4), 173-177. https://doi.org/10.1016/0160-9327(92)90044-P

Owolarafe, O., \& Faborode, M. (2008). Micro-structural characterisation of palm fruit at sterilisation and digestion stages in relation to oil expression. Journal of Food Engineering, 85(4), 598-605.

Payasi, A., Mishra, N. N., Chaves, A. L. S., \& Singh, R. (2009). Biochemistry of fruit softening: An overview. Physiology and Molecular Biology of Plants, 15(2), 103-113. https://doi.org/10.1007/s12298-009-0012-z

Razali, M. H., Halim, A. S. M. A., \& Roslan, S. (2012). A review on crop plant production and ripeness forecasting. International Journal of Agriculture and Crop Sciences (IJACS), 4(2), 54-63

Roongsattham, P., Morcillo, F., Jantasuriyarat, C., Pizot, M., Moussu, S., Jayaweera, D., Collin, M., GonzalezCarranza, Z. H., Amblard, P., Tregear, J. W., Tragoonrung, S., Verdeil, J., \& Tranbarger, T. J. (2012). Temporal and spatial expression of polygalacturonase gene family members reveals divergent regulation during fleshy fruit ripening and abscission in the monocot species oil palm. BMC Plant Biology, 12(150), 1-15. https://doi.org/10.1186/1471-2229-12-150

Sambanthamurthi, R., Let, C. C., Cheang, O. K., Huat, Y. K., \&Rajan, P. (1991). Chilling-induced lipid hydrolysis in the oil palm (Elaeis guineensis) mesocarp. Journal of Experimental Botany, 42(242), 11991205. https://doi.org/10.1093/jxb/42.9.1199

Sambanthamurthi, R., Sundram, K., \& Tan, Y. A. (2000). Chemistry and biochemistry of palm oil. Progress in Lipid Research, 39(6), 507-558. 
Sarah, M., \& Taib, M. R. (2013). Enzymatic destruction kinetics of oil palm fruits by microwave sterilization. International Journal of Chemical Engineering and Applications, 4(3), 129-133. https://doi.org/10.7763/ IJCEA.2013.V4.278

Siew, W. L. (2011). Edible oil processing - Palm oil milling process. The AOCS Lipid Library.

Silvamany, H., \& Jahim, J. M. (2015). Enhancement of palm oil extraction using cell wall degrading enzyme formulation. Malaysian Journal of Analytical Sciences, 19(1), 77-87.

Sivasothy, K. Ma, A. N., Maycock, J. H., \& Koichiro, Y. (1994) Combined sterilization-stripping process. Palm Oil Development, 19, 20-29.

Sivasothy, K., Basiron, Y., Suki, A., Taha, R. M., Hwa, T. Y., \& Sulong, M. (2006). Continuous sterilization: The new paradigm for modernizing palm oil milling. Journal of Oil Palm Research, (Special Issue), 144-152.

Sivasothy, K., Halim, R. M., \& Basiron, Y. (2005). A new system for continuous sterilization of oil palm fresh fruit bunches. Journal of Oil Palm Research, 17, 145-151.

Sivasothy, K., Hasan, M., \& Yaacob, M. (1992). Overview of automation in a palm oil mill - The sterilisation process. Computing \& Control Engineering Journal, 3(1), 45-52. doi.org/10.1049/cce:19920016

Sivasothy, K., \& Rohaya, M. H. (2000, May 18-19). Crushing and sterilization of fresh fruit bunches: a primising approach for continuous sterilization. [Paper presentation]. 2000 International Planters Conference, Kuala Lumpur, Malaysia.

Sukaribin, N., \& Khalid, K. (2009). Effectiveness of sterilisation of oil palm bunch using microwave technology. Industrial Crops and Product, 30(2), 179-183. https://doi.org/10.1016/j.indcrop.2009.05.001

Sultana, Y. (2007). Pharmaceutical microbiology and biotechnology-sterilization method and principles. Semantic Scholar.

Tan, Y., Kuntom, A., Siew, W., Yusof, M., \& Chong, C. (1999). Present status of crude palm oil quality in Malaysia. In Proceedings of the PORIM International Palm Oil Congress (pp.203-211). PORIM.

Tan, Y. A., Low, K. W., Lee, C. K., \& Low, K. S. (2010). Imaging technique for quantification of oil palm fruit ripeness and oil content. European Journal of Lipid Science and Technology, 112(8), 838-843. https:// doi.org/10.1002/ejlt.201000020

Teh, H. F., Neoh, B. K., Hong, M. P., Low, J. Y., Ng, T. L., Ithnin, N., Thang, Y. M., Mohamed, M., Chew, F. T., Yusof, H. M., Kulaveerasingam, H., \& Appleton, D. R. (2013). Differential metabolite profiles during fruit development in high-yielding oil palm mesocarp. PLoS One, 8(4), Article e61344. https:// doi.org/10.1371/journal.pone.0061344

Thang, Y. M., Ariffin, A. A., Appleton, D. R., Asis, A. J., Mokhtar, M. N., \& Yunus, R. (2017). Determination of sugars composition in abscission zone of oil palm fruit. In IOP Conference Series: Materials Science and Engineering (Vol. 206, No. 1, p. 012034). IOP Publishing.

Umudee, I., Chongcheawchamnan, M., Kiatweerasakul, M., \& Tongurai, C. (2013). Sterilization of oil palm fresh fruit using microwave technique. International Journal of Chemical Engineering and Applications, 4(3), 111-113. https://doi.org/10.7763/IJCEA.2013.V4.274 
Vincent, C. J., Shamsudin, R., \& Baharuddin, A. S. (2014) Pretreatment of oil palm fruits: A review. Journal of Food Engineering, 143, 123-131. https://doi.org/10.1016/j.jfoodeng.2014.06.022.

Walat, O., \& Ng, S. B. (2013). Palm oil mill OER and total oil losses. Palm Oil Engineering Bulletin, 108, 10-16.

Zulkifli, A. R., \& Ropandi, M. (2001). Fully stripped bunches in palm oil mills. MPOB Information Series, 111(127), 1-2. 